\title{
FINANCIAL ASSESSMENT OF FAGUS SYLVATICA STANDS IN LATVIA
}

\author{
Līga Puriṇa1 ${ }^{1}$, Andrejs Dreimanis² ${ }^{2}$ Annija Kārkliṇa ${ }^{1}$, Linards Sisenis ${ }^{2}$, Andis Adamovičs ${ }^{1}$, Mārtiṇš Puriṇšs ${ }^{1}$ \\ ${ }^{1}$ Latvian State Forest Research Institute 'Silava' \\ ${ }^{2}$ Latvia University of Agriculture \\ liga.purina@silava.lv
}

\begin{abstract}
European beech (Fagus sylvatica L.) timber value is high in southern Europe due to a great demand from Asia. Since the timber market is global, over a long time we can expect gradual increase in demand also in other countries, including Latvia, where climatic conditions becomes increasingly more suitable for this species due to ongoing climatic changes. In order to develop recommendation for the use of beech in our country, the aim of the study was to assess the potential financial gain from Fagus sylvatica stands in Latvia. Assortment structure, defined by topdiameter and length, as well as their prices was set based on the literature survey. Results showed higher income from older (115 years) than form younger (58 years) stands: $9108 \mathrm{EUR} \mathrm{ha}^{-1}$, and $7939 \mathrm{EUR} \mathrm{ha}^{-1}$, respectively. However, the opposite was true for the net present value $(\mathrm{r}=3 \%): 1423 \mathrm{EUR} \mathrm{ha}^{-1}$ and $304 \mathrm{EUR} \mathrm{Ha}^{-1}$, respectively.
\end{abstract}

Key words: European beech, noble broadleaves, NPV, introduced tree species.

\section{Introduction}

European beech (Fagus sylvatica L.) is one of the most widespread broadleaved tree species in central and western part of Europe. In the middle of the $19^{\text {th }}$ century, European beech was introduced in Latvia. Here beech trees grow in isolated areas outside of their natural distribution range (Purina et al., 2013). Climate envelope models suggest a significant shift of species distribution areas already by the end of this century (Hickler et al., 2012) and the conditions also in our country will become more favourable for European beech. However, due to slow natural migration and overwhelming human influence on forest ecosystem, beech might become more widespread in Latvia only in case if strategic decision of its wider use will be implemented. Such decision requires a sound basis, including analysis of potential financial viability as well as risks.

A number of studies so far have demonstrated a positive influence of already ongoing climatic changes on growth of trees in Latvia (Jansons et al., 2013a, 2013b; 2015a, 2016a; Rieksts-Riekstins et al., 2014). Climate-growth relationships for beech seem to be similar to native tree species, e.g. Scots pine (Jansons et al., 2016b), suggesting improvements also in growth of this tree species.

Beech wood market had been unstable in Europe; however, during last decade increasing tendencies had been observed due to export of its logs and saw-timber to Asia (Pöhler et al., 2005). The wood is highly appreciated for use in furniture, floorings as well as for plywood, veneering and pulp (von Wühlisch, 2011). Timber quality and value of beech trees depend on the tree traits and stand characteristics, site conditions and forest management (Poljanec et al., 2010). One of the most important traits determining assortment structure is branchiness (Haapanen et al., 1997; Purina et al., 2014). Also colour of beech wood important factors determining the price of the log (Pöhler et $a l ., 2005)$. The read heartwood in the living trees is

\section{Parameters of dominant beech trees in experimental sites}

Table 1

\begin{tabular}{|c|c|c|c|c|c|c|c|c|}
\hline $\begin{array}{c}\text { Experi- } \\
\text { mental site }\end{array}$ & $\begin{array}{c}\text { Area, } \\
\text { ha }\end{array}$ & $\begin{array}{c}\text { Age, } \\
\text { years }\end{array}$ & $\begin{array}{c}\text { Number of } \\
\text { trees, ha }^{-1}\end{array}$ & $\begin{array}{c}\text { Relative } \\
\text { number of } \\
\text { trees } \%\end{array}$ & $\begin{array}{c}\text { Basal } \\
\text { area, } \\
\mathrm{m}^{2} \mathrm{ha}^{-1}\end{array}$ & $\begin{array}{c}\text { Stand } \\
\text { volume, } \\
\mathrm{m}^{3} \mathrm{ha}^{-1}\end{array}$ & $\begin{array}{c}\text { Average } \\
\mathrm{DBH}_{1.3 \mathrm{~m}}, \mathrm{~cm}\end{array}$ & $\begin{array}{c}\text { Average tree } \\
\text { height, } \mathrm{m}\end{array}$ \\
\hline $21-27$ & 0.10 & 58 & 1270 & 100 & 54.5 & 637 & 23.0 & 23.2 \\
\hline $14-3$ & 0.10 & 58 & 650 & 100 & 32.7 & 374 & 24.8 & 23.1 \\
\hline $23-25$ & 0.2 & 101 & 424 & 87 & 31.3 & 408 & 30.7 & 27.0 \\
\hline $23-25$ & 0.2 & 115 & 395 & 100 & 34.3 & 456 & 32.2 & 27.2 \\
\hline $26-7$ & 0.45 & 105 & 222 & 86 & 36.7 & 520 & 45.9 & 30.5 \\
\hline $26-7$ & 0.45 & 110 & 193 & 84 & 38.2 & 555 & 50.2 & 31.5 \\
\hline $21-1$ & 0.30 & 115 & 280 & 100 & 35.7 & 474 & 40.3 & 27.9 \\
\hline $21-25$ & 0.33 & 101 & 364 & 100 & 42.8 & 686 & 38.7 & 33.8 \\
\hline $21-25$ & 0.33 & 115 & 352 & 100 & 47.9 & 786 & 41.7 & 34.8 \\
\hline
\end{tabular}

"Number of dominant beech trees related to number of all dominant trees in the stand. 
the cause of an important loss in timber quality thus also monetary value (Albert el al., 2003; Pöhler et al., 2005). Appearance of false heartwood also notably affects the potential use of beech wood (Johansson, 2005). Hillis (1987) indicated that the proportion of the false heartwood significantly increases with the tree age. Optimal harvesting age for beech is $80-$ 120 years (von Wühlisch, 2008) and value increases significantly with the dimensions of the tree (Poljanec \& Kadunc, 2013).

The aim of the study was to assess the potential financial gain from Fagus sylvatica stands in Latvia.

\section{Materials and Methods}

The study was done in European beech stands, located in the western part of Latvia, near to Skede $\left(57^{\circ} 14^{\prime} \mathrm{N}\right.$; $\left.22^{\circ} 39^{\prime} \mathrm{E}\right)$. Data from six repeatedly measured permanent sample plots $(0.10-0.45 \mathrm{ha})$ in Oxalidosa forest type with beech as dominant tree species (Tab. 1) were used. Measurements of individual tree height and $\mathrm{DBH}_{1.3 \mathrm{~m}}$ at different age were used to calculate assortment classes. Assortment outcome forecast was made using Donis (2009) improved Ozoliņš (2002) designed assortment algorithm.

Trees were divided into five assortment classes by their diameter according to Poljanec and Kadunc (2013), as described in Table 2. Analysis of economic value of experimental beech stands was based on beech wood prices used in Slovakia where beech is one of the tree species with great economically importance (Sisák, 2013). Experimental stands were joined into three groups according to their age: 1) 58, 2) 101, and 3) 115 years (including one stand, hat was measured also at the age of 110 years).

\section{Results and Discussion}

Three age groups of European beech (Fagus sylvatica L.) were analyzed in the study, to determine financial value of timber base on potential assortment structure (Tab. 2). For comparison National Forest Inventory (NFI) data on the most widespread broadleaved tree species in Latvia - birch (Betula pendula and Betula pubescens) were used. Its dimensions in stand on fertile mineral soils with

\section{Assortment classes by diameter at the top end and current monetary value}

Table 2

\begin{tabular}{|c|c|c|c|c|c|}
\hline \multirow[b]{2}{*}{ Assortment $^{\mathrm{a}}$} & \multirow[b]{2}{*}{ Length, $\mathrm{m}$} & \multicolumn{2}{|c|}{ Beech assortments $^{\mathrm{b}}$} & \multicolumn{2}{|c|}{ Broadleaved tree assortments $\mathrm{c}$} \\
\hline & & $\begin{array}{c}\text { diameter at the top } \\
\text { end, } \mathrm{cm}\end{array}$ & EUR $\mathrm{m}^{-3}$ & $\begin{array}{l}\text { diameter at the top } \\
\text { end, } \mathrm{cm}\end{array}$ & EUR $\mathrm{m}^{-3}$ \\
\hline Sawlogs I & 3 & $\geq 44$ & 150 & $\geq 26$ & 70 \\
\hline Sawlogs II & 3 & $38-43$ & 100 & $21-25$ & 65 \\
\hline Sawlogs III & 3 & $30-37$ & 64 & $18-20$ & 60 \\
\hline Industrial wood & 3 & $16-29$ & 50 & $14-17$ & 40 \\
\hline Firewood & 3 & $6-15$ & 41 & $6-13$ & 20 \\
\hline
\end{tabular}

a sawlogs I, II, III - large-sized, middle-sized and small-sized sawlogs, respectively;

${ }^{\mathrm{b}}$ according to Poljanec and Kadunc (2013);

${ }^{\mathrm{c}}$ according to data from Central Statistical Bureau (CSB) of Latvia (http://www.csb.gov.lv/).

\section{Assortment structure and income of beech}

\begin{tabular}{|c|c|c|c|c|c|c|c|}
\hline \multirow[b]{2}{*}{$\begin{array}{c}\text { Stand age, } \\
\text { years }\end{array}$} & \multirow{2}{*}{$\begin{array}{c}\text { Average } \\
\text { income, EUR } \\
\text { ha }^{-1}\end{array}$} & \multirow{2}{*}{$\begin{array}{c}\text { Net present } \\
\text { value, EUR } \\
\text { ha }^{-1}\end{array}$} & \multicolumn{5}{|c|}{ Proportion of assortments*, \% } \\
\hline & & & Sawlogs I & Sawlogs II & Sawlogs III & $\begin{array}{c}\text { Industrial } \\
\text { wood }\end{array}$ & Firewood \\
\hline \multicolumn{8}{|c|}{ Estimation according to beech wood in Slovakia (Sisák, 2013) } \\
\hline 58 & 7939 & 1423 & 0 & 0 & 0 & 56 & 32 \\
\hline 101 & 8513 & 430 & 0 & 6 & 25 & 48 & 10 \\
\hline 115 & 9109 & 304 & 0 & 9 & 35 & 39 & 6 \\
\hline \multicolumn{8}{|c|}{ Estimation according to broadleaved tree wood in Latvia (http://www.csb.gov.lv/) } \\
\hline 58 & 5602 & 1009 & 0 & 0 & 96 & 2 & 1 \\
\hline 101 & 6592 & 333 & 44 & 28 & 8 & 5 & 4 \\
\hline 115 & 7109 & 237 & 54 & 22 & 4 & 5 & 3 \\
\hline
\end{tabular}

*Assortments are described in Table 2. 
normal moisture regime (as in beech stands) at the age 58 years (roughly 10 years before the final harvest) were: mean breast height diameter $25.3 \mathrm{~cm}$, yield $248.8 \mathrm{~m}^{3} \mathrm{ha}^{-1}$, mean height $25.6 \mathrm{~m}$, basal area $21 \mathrm{~m}^{2} \mathrm{ha}^{-1}$. In beech stand at the same age mean breast height diameter was slightly (not significantly) smaller - $23.9 \mathrm{~cm}$, standing volume, due to high density - almost double that in birch stands, reaching $505 \mathrm{~m}^{3} \mathrm{ha}^{-1}$, mean height slightly lower, reaching $23 \mathrm{~m}$, basal area $43.6 \mathrm{~m}^{2} \mathrm{ha}^{-1}$. In 101 years old beech stand mean diameter was $38.4 \mathrm{~cm}$, but at the age 115 years $41.1 \mathrm{~cm}$, also standing volume in beech stand was slightly increasing with age and reached 538 and $568 \mathrm{~m}^{3} \mathrm{ha}^{-1}$, respectively, indicating a notable reduction of number of trees. Average tree height in older beech stands reached $30.4 \mathrm{~m}$; consequently, basal area was slightly lower than in younger stand, reaching $37 \mathrm{~m}^{2} \mathrm{ha}^{-1}$ at the age of 101 years and $39 \mathrm{~m}^{2} \mathrm{ha}^{-1}$ at the age of 115 years.

Even in the oldest stand included in analysis sawlog I dimensions (top-diameter for a $\log 44 \mathrm{~cm}$ ) had not been reached (Tab. 3). Also proportion of sawlog II assortments, presented in oldest stands (101 and 115 years) was small: $6 \%$ to $9 \%$, respectively. Proportion of saw-logs III assortment in the oldest stands ranged from $25 \%$ to $48 \%$, consequently three times lower portion of firewood was obtained than in younger (58 years) stands.

Calculated income from beech stands changed with its age: at the age of 58 years income from sales of timber assortments was 7939 EUR ha-1 $^{-1}$, at the age of 101 years (only $33 \mathrm{~m}^{3}$ more) - $8513 \mathrm{EUR} \mathrm{ha}^{-1}$, but at the age of 115 years $-9108 \mathrm{EUR} \mathrm{ha}^{-1}$. It is worth reminding, that incomes from potential commercial thinnings are not included in the analysis. Reverse trend was observed for the net present value changes with stand age - it was highest for youngest stands. It can at least partly be explained by absence of assortments of highest value in oldest stands.

Such assortment was present, if the dimensions used for the broadleaved tree wood assortment in Latvia currently were applied. In this case at the age of 58 years $96 \%$ of the timber was sawlogs III (diameter at the top end $18-20 \mathrm{~cm}$ ). Most of the trees reached the broadleaved saw-log dimensions at the age of 101 and 115 years: 44 to $54 \%$ of first and second class sawlogs, respectively.

Comparison of the timber value in birch and beech stand, considering the dimensions and volume as well as price differences, reveal, that financial value of beech stands at the age of 58 years is notably higher than that of birch stands. However, for neither of the tree species in our calculations the optimal management had been applied. Recent study in Latvia (not published) found, that in birch stand with low initial spacing financial value as high as 9900 EUR $\mathrm{ha}^{-1}$ can be reached already at the age of 40 years. Valkonen \& Valsta (2001) created birch economical models by cost and returns in mixed stands with spruce (no discounted value), and average net return varied from 1400 to $1900 \mathrm{EUR} \mathrm{ha}^{-1}$.

Considering the assortment structure Tullus et al. (2012) modeled, that at the age of 60 years on abandoned agricultural land in Estonia most of birch wood would be pulpwood (46-49\%), but in older stands playwood and energy-wood. It indicates, that for birch at the age of 58 years, similarly to beech in oldest stands in our assessment, the dimensions are still too small (sub-optimal) for final harvest, if the largest income in this operation is the goal.

In our study according to broadleaved tree dimensions, most of the assortments in beech stand at the age 58 were saw-logs III, that would represent a notably higher value than a pulpwood, suggesting a financial reason for use of this tree species in Latvia.

Net present value with interest rate of $3 \%$ in birch stands in Estonia was 1064 - 1104 EUR ha $^{-1}$ (Tullus et al., 2012; Niskanen; 1999). In Latvia, Dudelis (2013) assessed the financial value of birch stands at the age of 60,80 and 100 years. At the discount rate $3 \%$ the author achieved the values of 441, 532, 619 EUR $\mathrm{ha}^{-1}$, respectively. The estimates are comparable to those for beech stands in our study. In both cases value of admixture of other tree species in stand or branch quality were not considered. It has to be noted, that also possibility of occurrence of red heartwood for beech was not considered. It can significantly affect the financial value of beech timber. Richter (2001) found, that in North Rhine-Westphalia value loss of beech timber due to red heartwood reached as much 5.1 million EUR. Tree breeding might be required to avoid or improve quality traits as it has been demonstrated for other tree species in Latvia (Jansons et al., 2006, 2015b; Jansons, 2008).

Large dimensions are required for beech to obtain the highest financial gain; the value is increasing until the diameter of the trees reaches approximately $60 \mathrm{~cm}$. However, it is not reasonable to wait much longer, since the probability of formation of read heartwood for such large trees is high and the accumulated value can be lost (Poljanec \& Kadunc, 2013). Tree species comparison studies (Knoke, 2002; Knoke \& Seifert, 2008) reveal, that incomes from Norway spruce are stable, but in long term European beech may be profitable. Other study, carried out in Czech Republic (Aubrecht et al., 2016), had reported higher average timber price for Norway spruce $\left(83 \mathrm{EUR} \mathrm{m}^{-3}\right)$ than for beech (59 EUR $\mathrm{m}^{-3}$ ); however, such result might be influenced by different management regimes higher initial stand density and thus larger amount of firewood obtained from the beech stands. 


\section{Conclusions}

Mean height and breast height diameter of beech at the age of 58 years were similar to birch in fertile soils, but basal area and yield were notably higher. Monetary value of beech stand at the age of 101 year reached $8513 \mathrm{EUR} \mathrm{Ca}^{-1}$, but net present value $(\mathrm{r}=3 \%)$ was $430 \mathrm{EUR} \mathrm{ha}^{-1}$; if the beech wood would have to be sold as broadleaved saw timber its value at the same age would be notably lower: $6592 \mathrm{EUR} \mathrm{ha}^{-1}$, but net present value $333 \mathrm{EUR} \mathrm{ha}^{-1}$.

\section{Acknowledgements}

Initial assessment was carried out in project 'Adaptive capacity of forest trees and possibilities to improve it' (No 454/2012, Latvian Council of Science) development of manuscript - on project 'Forest management risks: prognosis and minimization' (JSC 'Latvija valsts meži').

\section{References}

1. Albert, L., Hofmann, T., Nemeth, Z.I., Retfalvi, T., Koloszar, J., Varga, S., \& Csepregi, I. (2003). Radial variation of total phenol content in beech (Fagus sylvatica L.) wood with and without red heartwood. Holz als Roh- und Werkstoff. 61, 227 - 230. DOI: 10.1007/s00107-003-0381-x.

2. Aubrecht, M.D., Helliker, R.B., Gouldenc, L.M., Roberts, D.Dar., Still, J.C., \& Richardsona, A.D. (2016). Continuous, long-term, high-frequency thermal imaging of vegetation: Uncertainties and recommended best practices. Agricultural and Forest Meteorology. 228 - 229, 315 - 326. DOI: 10.1016/j. agrformet.2016.07.017.

3. Donis, J. (2009). Latvijas meža resursu ilgtspējīgas, ekonomiski pamatotas izmantošanas un prognozēšanas modelı izstrāde. Pārskats par Meža attīstības fonda pasūtīto pētījumu (Development of sustainable, economically efficient models of forest resources in Latvia. Review of research ordered by the Forest development foundation.) LVMI Silava, Salaspils. 136 lpp. (in Latvian).

4. Dudelis, J. (2013). Development of stratified spruce-birch stands in Latvia. Swedish University of Agricultural Sciences Master Thesis no. 210, Southern Swedish Forest Research Centre, Alnarp.

5. Haapanen, M., Velling, P., \& Annala, M.L. (1997). Progeny trial of genetic parameters for growth and quality traits in Scots pine. Silva Fennica. 31, 3 - 12. DOI: 10.14214/sf.a8506.

6. Hickler, T., Vohland, K., Feehan, J., Miller, P.A., Smith, B., Costa, L., Giesecke, T., Fronzek, S., Carter, T.R., Cramer, W., Kuhn, I., \& Sykes, M.T., (2012). Projecting the future distribution of European potential natural vegetation zones with a generalized, tree species-based dynamic vegetation model. Global Ecology\& Biogeography, 21, 60 - 63.

7. Hillis, W.E. (1987). Heartwood and Tree Exudates, New York: Springer Verlag.

8. Jansons, Ā., Matisons, R., Šēnhofa, S., Katrevičs, J., \& Jansons, J. (2016b). High-frequency variation of tree-ring width of some native and alien tree species in Latvia during the period $1965-2009$. Dendrochronologia, 40, $151-158$.

9. Jansons, Ā. (2008). Genotype-environment interaction in Latvian Scots pine growth and quality traits and its impact to progeny testing. In Research for Rural Development 2008: International Scientific Conference Proceedings, 21 - 23 May 2008 (pp. 128 - 136). Jelgava, Latvia: Latvia University of Agriculture.

10. Jansons, Â., Baumanis, I., Dreimanis, A., \& Gailis, A. (2006). Variability and genetic determination of Scots pine quantitative traits at the age of 32 years. In Research for Rural Development 2006: International Scientific Conference Proceedings, 17 - 20 May 2006 (pp. 289 - 295). Jelgava, Latvia: Latvia University of Agriculture.

11. Jansons, A.., Donis, J., Danusevičius, D., \& Baumanis, I. (2015b). Differential analysis for next breeding cycle for Norway spruce in Latvia. Baltic Forestry 21(2), 285 - 297.

12. Jansons, A., Matisons, R., Baumanis, I., \& Purina, L. (2013a). Effect of climatic factors on height increment of Scots pine in experimental plantation in Kalsnava, Latvia. Forest Ecology and Management, 306, 185 $-191$.

13. Jansons, A., Matisons, R., Libiete-Zālīte, Z., Bāders, E., \& Rieksts-Riekstiñ̌̌, J. (2013b). Relationships of height growth of lodgepole pine (Pinus contorta var. latifolia) and Scots pine (Pinus sylvestris) with climatic factors in Zvirgzde, Latvia. Baltic Forestry, 19(2), 236 - 244.

14. Jansons, A.., Matisons, R., Zadina M., Sisenis, L., \& Jansons, J. (2015a). The effect of climatic factors on height increment of Scots pine in sites differing by continentality in Latvia. Silva Fennica, 49(3), id 1262. 14 p. DOI: $10.14214 /$ sf. 1262 .

15. Jansons, A., Neimane, U., Dzerina, B., \& Adamovics, A. (2016a). Influence of lammas shoots on height of young Scots pines in Latvia. Agronomy research, 14(2), 407 - 417. 
16. Johansson, J. (2005). Product differentiation in the Swedish hardwood sawmill industry. Växjö University, School of Technology and Design, Report No 25, ISBN 91-7636- 489

17. Knoke, T. (2002). Value of complete information on red heartwood formation in beech (Fagus sylvatica). Silva Fennica. 36(4), 841 - 851. DOI: 10.14214/sf.525.

18. Knoke, T., \& Seifert, T. (2008). Integrating selected ecological effects of mixed European beechNorway spruce stands in bioeconomic modelling. Ecological modeling. 210, 487 - 498. DOI: 10.1016/j. ecolmodel.2007.08.011.

19. Niskanen, A. (1999). The financial and economic profitability of field afforestation in Finland. Silva Fennica. 33(2), 145 - 157. DOI: 10.14214/sf.664.

20. Ozolins, R. (2002). Forest stand assortment structure analysis using mathematical modelling. Forestry Studies. Metsandus Likud Uurimus. 37, $33-42$.

21. Pöhler, E., Klingner, R., \& Künniger, T. (2005). Beech (Fagus sylvatica L.) - Technological properties, adhesion behaviour and colour stability with and without coatings of the red heartwood. Annals of Forest Science. 63, 129 - 137. DOI: 10.1051/forest:2005105.

22. Poljanec, A., \& Kadunc, A. (2013). Quality and timber value of European beech (Fagus sylvatica L.) trees in the Karavanke Region. Croatian Journal of Forest Engineering. 34(1), 151 - 165. Retrieved March 2, 2017, from: http://hrcak.srce.hr/116737.

23. Poljanec, A., Ficko, A., \& Boncina, A. (2010). Spatiotemporal dynamic of European beech (Fagus sylvatica L.) in Slovenia, 1970 - 2005. Forest Ecology and Management. 259, 2183 - 2190. DOI: 10.1016/j.foreco.2009.09.022.

24. Purina, L., Neimane, U., Baumane, A., Katrevics, J., \& Jansons, Ā. (2014). Parastās priedes (Pinus sylvestris L.) pluskoku stumbra kvalitāte (Quality of Scots pine (Pinus sylvestris L.) plus-trees.) Mežzinātne. 28(61). (in Latvian).

25. Puriņa, L., Neimane, U., Džeriņa, B., \& Jansons, Ā. (2013). Eiropas dižskābarža (Fagus sylvatica L.) atjaunošanos ietekmējošie faktori (Factors affecting regeneration of European beech (Fagus sylvatica L.).) Mežzinātne. 27(60). (in Latvian).

26. Richter, J. (2001). Buchenrotkern: Vermeiden oder Verwerten? (Redwoods: Avoid or recycle?) Forst und Holz, 56, 662 - 664. (in German).

27. Rieksts-Riekstins, J., Jansons, A., Smilga, J., Baumanis, I., Ray, D., \& Connolly, T. (2014). Climate suitability effect on tree growth and survival for Scots pine provenances in Latvia. In Research for Rural Development 2014: International Scientific Conference Proceedings, 21 - 23 May 2014 (pp. 57 - 62). Jelgava, Latvia: Latvia University of Agriculture.

28. Sisák, J. (2013). Cenník sortimentov surového dreva. (Price list of assortments of raw wood). Technická univerzita vo Zvolene - Vysokoškolský Lesnícky Podnik, Zvolen, 5 p. (in Slovak).

29. Tullus, A., Lukason, O., Vares, A., Padari, A., Lutter, R., Tullus, T., Karoles, K., \& Tullus, H. (2012). Economics of Hybrid aspen (Populus tremula L. x P. tremuloides Michx) and Silver birch (Betula pendula Roth.) plantations on abandoned agricultural land in Estonia. Baltic Forestry. 18(2), 288 - 298.

30. Valkonen, S., \& Valsta, L. (2001). Productivity and economics of mixed two-storied spruce and birch stands in Southern Finland simulated with empirical models. Forest Ecology and Management. 140, 133 - 149. DOI: 10.1016/S0378-1127(00)00321-2.

31. Von Wühlisch, G. (2008). EUFORGEN Technical Guidelines for genetic conservation and use for European beech (Fagus sylvatica). Bioversity International, Rome, Italy. 6 p. 